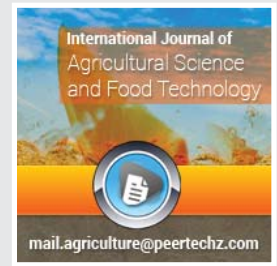

\section{Bekele Tsegaye*}

Areka Agricultural Research Center, Southern

Agricultural Research Institute, Ethiopia

Received: 21 December, 2018

Accepted: 10 May, 2019

Published: 13 May, 2019

*Corresponding author: Bekele Tsegaye, Areka

Agricultural Research Center, Southern Agricultural Research Institute, P.O. Box: 79, Areka, Ethiopia, Tel: +251911893571; Fax: +251465520502;

E-mail: tsegkid2003@gmail.com

Keywords: Land use; Land cover; Degradation; Soil erosion; Ethiopia

https://www.peertechz.com

Check for updates
Review Article

\section{Effect of Land Use and Land Cover Changes on Soil Erosion in Ethiopia}

\begin{abstract}
Land degradation is one of a serious agricultural problem that posed severe threat to food production and the livelihood of peoples in Ethiopia. It resulted in high economic loss and threat in natural environment. The country loses about $\$ 106$ million annually through soil and nutrient loss. Soil degradation is the one and the major form of land degradation that have been stayed for long period as the bottlenecks of the country's economy and human wellbeing. The economic loss soil degradation in the form of soil erosion and nutrient depletion only from the highlands of the country is about $10-11 \%$ of agricultural gross domestic products. Soil erosion is one of the major causes of soil degradation in the country. The annual soil loss rate on average is about 42 tones/ha for croplands, and up to 300 tones/ha in extreme cases. The average total soil loss of the country is estimated as 12 ton/ha/year, which varied based on land cover types. Ethiopia historically passed significant dynamics in land use/land cover since long ago to date. Land use and land cover changes and degradation are increasing at alarming rate generally throughout the country. The change in land use types played a significant role in this increased rate of soil erosion in Ethiopia. Cultivated lands showed continuously increasing trend the expense of forest and grasslands. The rapidly increasing population has led to a declining availability of cultivable land and a very high rate of soil erosion. The objective of this review paper is to view the effect of Land Use-Land Cover change in soil erosion in Ethiopia
\end{abstract}

\section{Introduction}

Land degradation has become an important concern generally in the world, and the same is true specifically in Ethiopia, because of its implications for food security and the environment. Ethiopia is known for its historic agriculture, but also for the associated, widespread, and ongoing land degradation [1]. Land degradation is one of a serious agricultural problem that posed severe threat to current and potential food production and the livelihood of peoples in Ethiopia [2,3]. Some studies before few years indicated as the annual costs of land degradation relate to soil erosion and nutrients loss from agricultural and grazing lands is estimated at about $\$ 106$ million from a combination of soil and nutrient loss $[4,5]$. Due to the favorable climatic conditions and fertile soils, known to be the oldest settled high land areas of the country land degradation stems from the historical development of agriculture and human settlement in these areas and latter progressively increased with significant rate [6]. The shortage of land, rapid growth of population and demand for increased food production intensified the pressure on the land and aggravated the process of land degradation [7].

There is no doubt that the major cause for land degradation in Ethiopia is known as inappropriate use of land for different economic activities. Human activities contributing to land degradation such as deforestation, removal of natural vegetation, overgrazing, and agricultural intensification without erosion control measures sustained for long period by deteriorating land [8]. Girma, indicated the major causes of land degradation in Ethiopia as rapid population increase, severe soil loss, deforestation, low vegetative cover and unbalanced crop and livestock production. Besides the human induced causes, factors such as land topography, ecology, rainfall, land cover and soil types counted as being as proximate and underlying causes of land degradation in Ethiopia (Ayalnen, 2003, cited in Deresa and Legesse, 2015). Large areas abandoned or managed at low levels productivity and affecting $20-50 \%$ of the land and some 6 - 11 million people each year and continued till present as the greatest threat to the survival of the nation [9].

Soil degradation is the key component of land degradation, and there is almost no form of land that does not include soil degradation [10]. Many definitions are given for the term 'soil degradation'. It is the decline in soil quality leading to a reduction in other components of land resources (e.g. vegetation, water, and air) [8]. Soil degradation is a narrower term for declining soil quality, encompassing the deterioration in physical (e.g., soil erosion, compaction, and waterlogging), chemical (e.g., nutrient depletion and acidification) and biological (e.g., soil organic matter decline and depletion of soil 
fauna) attributes of the soil [11,12]. In Ethiopia different forms of soil degradation have been stayed as the bottlenecks of the country's economy and human wellbeing. Approximately, $17 \%$ of the potential agricultural Gross Domestic Product (GDP) is being lost because of soil degradation [13]. In Drechsel and Gyiele, cited in Berry et al., it was indicated as the annual economic loss of the country because of soil degradation in the form of soil erosion and nutrient depletion as $10-11 \%$ of agricultural gross domestic products from the highlands of the country. In these highlands of the country, soil degradation reached at the level of severe which led to lower yield or higher costs of inputs so that the food security of present and future generations is being threatened, as the smallholder farmers in the area largely depend upon the land for their livelihood $[14,8]$

Soil erosion is one of the major causes of soil degradation along with soil compaction, low organic matter, loss of soil structure, poor internal drainage, salinization, and soil acidity problems [15-17]. Soil erosion is a physical process that causes land and soil degradation, and refers to the displacement of soil particles by water, wind and/or forces associated with farming activities such as tillage that eventually results in reduction in soil productivity due to physical loss of topsoil, reduction in rooting depth, removal of plant nutrients, and loss of water. Topsoil, which is high in organic matter, fertility and soil life, is relocated elsewhere "on-site" where it builds up over time and results in onsite effect such as reduces cropland productivity or is carried "off-site" where it fills in drainage channels and results in offsite effect like contribution to the pollution of adjacent watercourses, wetlands and lakes. The rapid growth of demand for food related with population growth increased the need for cultivated land that in turn put pressure on land and leading to loosening of soil structure and cohesion which made the soil easily lost by erosion [18].

In Ethiopia, soil erosion by water is the dominant degradation process and occurs particularly on cropland, with annual soil loss rates on average of 42 tones/ha for croplands, and up to 300 tones/ha in extreme cases [19]. The average total soil loss of the country before some three decades was estimated as 12 tone/ha/year which varied based on land cover types as high as 70 ton/ha/year in unproductive lands to as low as 1 ton/ha/year in forest lands [20]. Despite the fact that the country's government effort in massive and vast participation in prevention of soil erosion through implementation of different soil and water conservation works [21-23], there are still reports as the soil rate of the country is still increasing. Though the estimate was in smaller area size, different land use definition than Huri (1989) and mainly focused on cropping lands, still the average soil loss rate of the country is about 18 ton/ha/year and nearly 1 billion tones of suspended sediments originating from human-induced soil erosion still reach the rivers every year [1].

The change in land use types played a significant role in this increased rate of soil erosion in Ethiopia. Cultivated lands showed continuously increasing trend at the expense of forest and grasslands over the last four decades $[24,25]$. Land use change is the conversion of land use due to human intervention for various purposes, such as for agriculture, settlement, transportation, infrastructure and manufacturing, parks, recreation uses, mining and fishery $[26,27]$. In Ethiopia, the rapidly increasing population has led to a declining availability of cultivable land and a very high rate of soil erosion [28]. In general term, the historic land use and land cover change in Ethiopia had induced great impact on biodiversity, water resources, forest and local livelihoods of the country [22]. Due to deforestation and permanent removal of other vegetation in Ethiopian highlands before some few years, about 27.5 million ha of the areas examined showed significant signs of accelerated soil erosion, while about 14.5 million ha of land were considered the 'worst affected areas' and were recommended to be abandoned [29]. Therefore, from this we can see the close relationship between land use-land cover change with soil erosion narrow view and land degradation in general.

\section{Objective}

The objective of this review paper is to view the effect of Land Use-Land Cover (LuLc) change in soil erosion in Ethiopia.

\section{Some basic concepts}

It is important to define and distinguish related concepts such as land degradation, soil degradation, and soil erosion, as these are sometimes (incorrectly) used interchangeably. One should understand where the terms are different and again their relationships for ease and standard communication. The other confusing terms are also the terms 'land use' and 'land cover'. In some cases the two terms used interchangeably which does not means that the terms are one and the same in all cases.

Land degradation is a broad term, reflecting the fact that land itself is a broad term, including more than just the soil. The U.N. Convention to Combat Desertification defines land as "the terrestrial bio-productive system that comprises soil, vegetation, other biota, and the ecological and hydrological processes that operate within the system", and land degradation as "reduction or loss of the biological or economic productivity and complexity of rainfed cropland, irrigated cropland, or range, pasture, forest and woodlands resulting from processes such as (i) soil erosion caused by wind and/or water; (ii) deterioration of the physical, biological or economic properties of the soil; and (iii) long-term loss of natural vegetation" [30]. In Fitzpatrick, land degradation is also defined as is the systematic decline in the quality of land resulting from a mismatch between land use and land quality. Land degradation is defined as the temporary or permanent decline in the productive capacity of the land, and the diminution of the productive potential, including its major land uses (e.g., rain-fed arable, irrigation, forests), its farming systems (e.g., smallholder subsistence), and its value as an economic resource [31]. UNCCD also defines land degradation as a persistent decline in the ability of a ecosystem to provide goods and services associated with primary production [32]. Therefore, land degradation is more general term that it is a 'situation' or 'from' of land that do not stand alone that caused by other factors such as soil erosion, acidification, pollution, 
etc. It is a complex phenomenon influenced by natural and socio-economic factors.

Soil degradation is a narrower term, and one form of land degradation, for declining soil quality, encompassing the deterioration in physical, chemical and biological attributes of the soil [11]. Soil compaction, low organic matter, loss of soil structure, poor internal drainage, salinisation and soil acidity problems are other serious soil degradation conditions that can accelerate the soil erosion process [18]. Soil degradation refers to the decline in a soil's inherent capacity to perform environmental and socio-economic functions. The problem usually caused by many factors including excessive tillage, inappropriate crop rotations, excessive grazing or crop residue removal, deforestation, mining, construction and urban sprawl [33]. Some soil degradation processes are natural phenomena but they are exacerbated by all kinds of unsustainable human uses. Causes of degradation include deforestation, overgrazing, agricultural practices, overexploitation of the vegetative cover, and industrial activities.

Soil erosion is one of the causes of soil degradation and it refers to the wearing away of a field's topsoil by the natural physical forces of water and wind. Topsoil, which is rich in organic matter, high fertility and soil life, is relocated elsewhere "on-site" where it builds up over time or is carried "off-site" where it fills in drainage channels [18]. The different forms of Soil erosion described in Wright and Adamseged, as it includes a range of phenomena such as sheet erosion (the removal of thin layers of topsoil from an eroded site), rill and gully erosion (the formation of small incised rills or large gullies on a slope), mass wasting (the structural failure of part of a hillside as in the case of a landslide); wind erosion, tunnel erosion (caused by percolation of groundwater through a porous mantle) and fluvial (stream bank) erosion. It is removal of topsoil faster than the soil forming processes can replace it, due to natural, animal, and human activity (over grazing, over cultivation, forest clearing, mechanized farming, etc.). Soil erosion, whether it is by water, wind or tillage, involves three distinct actions soil detachment, movement and deposition. It reduces cropland productivity and also contributes to the pollution of adjacent watercourses, wetlands and lakes. It is one of the major causes of soil degradation. The worst case of soil erosion is that results in land infertility and in extreme case lead to desertification and devastating flooding.

Therefore, land degradation is a general terms that used to describe degradation in environment and it is manifested in different forms. Soil degradation is just one, but most important, form of land degradation. These two terms are of course the final problems in land which caused by different factors. Soil erosion is one of the significant factors/causes of soil degradation alongside with other factors.

Land use and land cover have some fundamental differences. Coffey (2013), Comber et al., put the difference between the two terms as

Land use refers to the purpose the land serves, for example, recreation, wildlife habitat or agriculture; it does not describe the surface cover on the ground. For example, a recreational land use could occur in a forest, shrub land, grasslands or on manicured lawns.

Land cover refers to the surface cover on the ground, whether vegetation, urban infrastructure, water, bare soil or other; it does not describe the use of land, and the use of land may be different for lands with the same cover type. For instance, a land cover type of forest may be used for timber production, wildlife management or recreation; it might be private land, a protected watershed or a popular state park.

Therefore, land use indicates how people are using the land, whereas land cover indicates the physical land type. Hence, understanding both the land use and land cover of a land provides a comprehensive picture of a particular area and is fundamental component of the planning and decision-making processes for many communities.

\section{Soil Erosion in Ethiopia}

Soil erosion is recognized as one of the most serious causes of soil degradation in Ethiopia $[34,15,16,35]$ and hence in highland areas of the country the crop yield and soil fertility levels are extremely low [36]. Continued soil erosion seriously threatens peoples' livelihoods, especially in highland parts of the country, where arable land is a very scarce resource [37]. Annually about 2 billion cubic meter top soil loss is reported for the country $[1,6,38]$. Ethiopia losses over 1.5 billion tons of topsoil annually only from the highlands due to erosion [8]. The average annual soil loss rates from crop lands estimated as 42 tones/ha, and ranged up to 300 tones/ha in extreme cases [19]. Especially the productive highland parts of the country, which characterized by rugged topography, densely populated, intensive cultivation and that host large proportion of people and livestock, harmed highly with problem of land degradation[22,39,40]. About $43 \%$ of the total highland areas of Ethiopia are highly affected by soil erosion with an estimated average annual loss of 20 ton per hectare and measured annual amounts of more than 300 ton per hectare on specific plots $[41,42]$. Only the Blue Nile basin of the country loses fertile soils with a rate of 131 million ton per year [35]. Not only the highlands, but also the dry lowland areas of the country have also been identified as vulnerable to the problem of land degradation [43].

In Ethiopia the annual costs of land degradation relate to soil erosion and nutrients loss from agricultural and grazing lands is estimated at about \$106 million (about 3\% of agricultural GDP) from a combination of soil and nutrient loss [4,5]. The food security of present and future generations is being threatened due to soil erosion, as the smallholder farmers in the area largely depend upon the soil for their livelihood, and farmers are changing land use from cropland to plantation forest (e.g., Eucalyptus globulus) responding to soil degradation mainly by soil erosion [8]. Bojo and Cassells (1995) related various reports on rates of soil loss per annum with relative decline in yield and obtained average decline of 0.4 percent per year for all cereals as a function of soil loss. The report on the damage of soil erosion in economic term indicated as Ethiopia losses USD 1 billion annually [7]. The average national nutrient balances loss 
rate of the country reported out of their independent research works as $47 \mathrm{~kg} \mathrm{~N}$ ha-1, $15 \mathrm{~kg}$ P2O5 ha-1 and $38 \mathrm{~kg} \mathrm{K2O} \mathrm{ha-1} \mathrm{[44]}$ and latter Haileslassie et al. (2005) reported estimated national nutrient depletion rates as $122 \mathrm{~kg} \mathrm{~N}$ ha-1 y-1, $13 \mathrm{~kg}$ P ha-1 y-1 and $82 \mathrm{~kg} \mathrm{~K} \mathrm{ha-1} \mathrm{y}-1$. If no proper measures are taken to protect the soil, intensive agriculture to meet the increasing demand for food will accelerate soil erosion in the country (Gelaw et al., 2013, cited in Adugna et al., 2015).

Most of the factors contributing for soil erosion in the country are human induced [45]. Most cultivated lands in the hills and mountains of the country have suffered from loss of top soil, leaving bare stones. Gullies are observed everywhere in the deep soils [36]. It caused strong environmental impacts and major economic losses from decreased agricultural production and from off-site effects on infrastructure and water quality by sedimentation processes $[46,47]$. It has put a substantial threat in agriculture of the country. Out of a total surface area of 112 million hectares, the estimates made in the mid 1980 s showed that about 27 million hectares are significantly eroded, 14 million hectares are seriously eroded and 2 million hectares have reached the point of no return $[34,48]$.

What is the main cause for this persisted worst situation in soil degradation in Ethiopia? What is its effect on the environment? What are the economic and social impacts? Why different efforts in areas of soil and water conservation have been ineffective in bringing the desired impact? There have been various research works by local, national and international research institutions since 1980s focused on answering such questions and indeed brought significant contribution in improvement of awareness and direction in areas of soil and water conservation in the country. Some of the major factors reported include education/experience [14], pressure on the land [49], institutional problems [3], economic incentives [50], political stability and social status [51]. The annual deforestation rate of $3.1 \%$ due to expansion of farmland, shifting cultivation, commercial agriculture, fuel wood collection, commercial logging, urbanisation is reported for Oromia region [52]. The original $65 \%$ of total forest coverage of the country was reduced to $16 \%$ in 1950 s, $2.7 \%$ in 1990 and $2.2 \%$ in 2000 with deforestation rate of 150,000 ha per year (Ethiopian Forestry Action Plan report) or 62,000 ha per year (World Bank report) [53] before few years. Mushir and Kedru, (2012) reported the unsuccessful history in areas of soil and water conservation as also lack of involvement of farmers in the planning and implementation, introduction of unfit the measures to local condition, costy nature of the structures, and uniform application of similar soil and water conservation measures disregarded local agroecological and socio-economic variations as some of the reasons for past failure.

\section{Land Use-Land Cover dynamics in Ethiopia}

Understanding the dynamics in land use/land cover change is increasingly important issue in study of environmental change for assessing and figuring the current resource status and planning sustainable resource management options. Not only the dynamics but also knowing the direction of dynamics, the cause and how this change is benefiting or harming the natural environment and the people is very important. It is claimed that there is constant change in land cover-land use with interaction of human being and resulted in modification of environment and its service. A land cover change, particularly deforestation, has become a global concern, with dynamic implication for human livelihood system [54]. Natural land covers have been transformed to agricultural lands and urban areas to meet the increasing demands for food, water, consumption of goods and other public utilities for over six billion people worldwide (Amare and Kameswara, 2011, cited in Amare and Gebeyehu, 2017).

Land use conversion due to increasing human and livestock population is a common experience in eastern African countries like Ethiopia through inappropriate agricultural practices and high human and livestock population pressure that led to sever land degradation in the country (Alemu, 2015, cited in Mammo et al., 2018). Land use dynamics is one of the major environmental problems in Ethiopia. Estimates of deforestation in Ethiopia, which is mainly for expansion of rain fed agriculture, vary from 80,000 to 200,000 ha per annum (EPA, 1997, cited in Temesgen et al., 2014). The highland parts of the country which cover the major portion of the country $(40 \%$ of the total area of the country), characterized by high human and livestock population pressure, high land fragmentation, rapid expansion of agricultural land extensive cultivation eventually resulted in high land degradation [28]. Land use and land cover changes and degradation are increasing at alarming rate in the highlands of Ethiopia [55] that led to the transformation of natural habitats to other land use types [56]. Farmers often push onto steeper and steeper slopes for crop farming which can only give yields for a few years before the soil is washed away. Rapid population growth which resulted in rapid agricultural expansion at the expense of the forest resource and free grazing system aggravates the depletion of the ecosystem including soil erosion and water resource degradation [57].

Though the figurative nationwide change information in land use/land cover is limited, there are different watershed and basin wide reports. In Gumara watershed of Lake Tana basin forest land, shrub land, grass land and wetland declined by $85.30,91.39,76.15$ and $72.54 \%$, respectively, within 28 years [58]. The cultivated land and settlements increased by 15.4 and $9.9 \%$, respectively, at the expense of shrub land and grazing lands in Gilgel Tekeze watershed in the highlands of Northern Ethiopia within 28 years [59]. The cultivated was increased by 7054.6 ha while grass, wetland and bush lands decreased by $4846.5,511.9$ and 3376 ha, respectively, in Koga watershed of North Western Ethiopia for demand for cultivated land and fuel wood [60]. There was 59\% increment in cultivated land at the expense of grass, shrub and forest lands and a decrease of $25.5 \%, 14 \%$ and $20.5 \%$ of grass, shrub and forest land within 37 years in Huluka watershed of Central Rift Valley of Ethiopia [61]. The forest coverage became smaller and more fragmented and declined from 202.6 ha to $101 \mathrm{~h}$ between years 1985 and 2011 due to an extensive and massive clearance of forests and grasslands in Lake Haramaya Watershed [62].

In Ethiopia, previous studies reported that there have been considerable land use/land cover changes in different 
parts of the country over the different time periods [24]. The land use/land cover change due to high population pressure and the associated depletion of the scarce resources have made agriculture of the country unsustainable, forcing its expansion into marginal areas such as steep slopes, swampy plains, and traditionally untapped part of the environment and putting tremendous pressure on soil, vegetation and water resources [63]. The main land use/land cover change in Ethiopia manifested through changing cultivated land at the expense of forest lands. Agriculture, timber extraction, fuel wood collection and charcoal production are said to be main direct drivers of deforestation while others such as population growth, demand for commodities, economic growth and weak governance are considered to be among indirect drivers of deforestation [64]. In years between 1965 to 1994 only, there was a strong decrease of the forest and bush land in favor of arable land and rangeland in Eastern Tigray region [65] and in some North West Ethiopia there was a significant increase in cultivated land at the expense of forests during the period of 1965 to 1994 [24].

There are different watershed based study reports on the impacts of land use and land cover changes on the hydrological flow regime. The impact is through altering the balance between rainfall and evaporation and the runoff response. Muluneh and Arnalds reported an increment of a direct runoff in Gum-Selassa and Maileba catchments annually from 1964 to 2006 in both catchments due to long-term changes of land use and land cover. A similar study reported the drying of Lake Cheleleka and the disappeared Lake Haramaya due to these long-term impacts. It was also reported by Geremew, that land use and land cover changes affected the stream flow of Gilgel Abbay watershed, Ethiopia. His study identified that there was an increase of stream flow by $16.26 \mathrm{~m}^{3} / \mathrm{s}$ during wet months as a consequence of conversion of cultivated land. The hydrological regime of Blue Nile and Lake Tana basins has been strongly modified by intensive agricultural activities, over the past few decades [66].

\section{Land Use/Land cover change and soil erosion in Ethiopia}

Land use/land cover changes and land degradation are highly interrelated $[67,68]$ because usually the changes are associated with deforestation, biodiversity loss and land degradation [69]. Land cover is one of the factors that determine the rate of soil loss due to erosion. Belay, stated that land use/land cover changes towards cultivated land aggravate soil erosion problems unless proper management is undertaken. A study by Hurni and Ludi, also reveals that human land use around the Simen Mountains National Park has accelerated the degradation of vegetation and soils. Changes in land use/land cover has significant impacts on the socioeconomic and environmental systems functioning with tradeoffs for sustainability, food security, biodiversity and the vulnerability of people [70].

Most of land use/land cover change in Ethiopia is in the form of changing forest and shrub lands to cultivation [71]. Removal of vegetation cover means exposing the land to soil erosion because process accelerates removal of soil particles and increased sheet, rill and gully erosions by reducing the protection of soil cover. In the highlands of Ethiopia, significant land cover changes have been observed since the last century due to a long history of agricultural practices and human settlement that recently resulted in high population pressure including unsustainable practices and depletion of the natural resources including soil $[24,34]$. This resulted in the soil degradation, mainly in the form of soil erosion, to be in worse sate. The estimate in mid 1980 s by FAO, indicated as about half of the highlands' land area of Ethiopia was "significantly eroded" and over one-fourth was "seriously eroded" and over two million hectares of farm lands had reached the "point of no return" in the sense that they are unlikely to sustain economic crop production in the future.

There are different watershed and basin based studies reported the impact of land use/land cover changes in erosion. The study report before few years indicated as Gojam area has undergone dramatic land use and land cover changes, with the result that almost all land units have been converted to cultivated land [24]. The result of Soil Conservation Research Project on 10oha soil loss monitoring catchment in Gojam showed annual soil loss from cultivated lands ranges from 130 to $170 \mathrm{t} / \mathrm{ha} / \mathrm{yr}$ [72]. Bosshart, reported as the average annual suspended sediment yield from the unconserved parts of the catchment reached $61 \mathrm{t} / \mathrm{ha} / \mathrm{y}$, higher than the country average. The $52 \%$ increment in cultivated land with the expense of forest and grass lands in Genale watershed, Southern Ethiopia, increased the soil loss rate by 189 percent within 3 decades (1985 to 2015) with predicted soil loss rate of 41 ton/ha/year in year 2015 [73].

Land use and land cover changes and degradation of natural resources, particularly vegetation and soils, are increasing at alarming rate in the highlands of Ethiopia [55]. Most mountainous areas in north western part of the country severely threatened by the agricultural land expansion and livestock overgrazing which would ultimately lead to excessive soil erosion and disrupting hydrological system of the area [57]. The dramatic increase in both livestock and human population due to migration from the surroundings in Abjitata Shala national park area induced high pressure in the environment that resulted in the conversion of natural vegetation, into cultivated and bare lands through overgrazing of natural grasslands, removal of natural shrub for fire wood, and clearing of forests for construction materials and charcoal making which eventually resulted in changes in land use/land cover and hence vulnerable sloping areas in the area face increased erosion and depletion of nutrients required for vegetative growth [55].

The major impact of land use/land cover changes in the livelihood of rural communities indicated in Belay (2018) include: its impact on land resources with related to land degradation, soil erosion, and productivity decrement; its impacts on environment thereby rural communities' vulnerability to climate vagaries; vulnerability of rural communities towards erratic rain fall and water sources problem with related to the change; impact on access to quality water; its negative impact on livestock rearing which related with grazing land shrinkage for agricultural land expansion, and also its impacts on ecosystem goods and services especially related with deforestation. 
Therefore, information on land use/land cover changes, its ultimate impact and possibilities for their optimal use is essential for the selection, planning and implementation of land use schemes to meet the increasing demands for basic human needs and welfare. In Ethiopian condition there is an urgent need to design and implement appropriate land management options, coupled with population control and sustainable natural resource use and conservation that meet the need of both present and future generations [74-90].

\section{Summary and Conclusion}

Land degradation is one of a serious agricultural problem that posed severe threat to current and potential food production and the livelihood of peoples in Ethiopia. The shortage of land, rapid growth of population and demand for increased food production intensified the pressure on the land and aggravated the process of land degradation. It resulted in high economic loss and threat in natural environment. The country loses about \$106 million annually through soil and nutrient loss. Inappropriate use of land contributing to land degradation such as deforestation, removal of natural vegetation, overgrazing, and agricultural intensification without erosion control measures sustained for long period by deteriorating land. Large areas of the country abandoned or managed at low levels productivity and affecting land and the dwelling peoples.

Soil degradation is the one and the major form of land degradation that have been stayed for long period as the bottlenecks of the country's economy and human wellbeing. Approximately, $17 \%$ of the potential agricultural Gross Domestic Product of the country is being lost because of soil degradation. The economic loss soil degradation in the form of soil erosion and nutrient depletion only from the highlands of the country is about $10-11 \%$ of agricultural gross domestic products

Soil erosion is one of the major causes of soil degradation in the country. The annual soil loss rate on average is about 42 tones/ha for croplands, and up to 300 tones/ha in extreme cases. The average total soil loss of the country is estimated as 12 tone/ha/year which varied based on land cover types as high as 70 ton/ha/year in unproductive lands still with an indication of increasing trend. About $43 \%$ of the total highland areas of Ethiopia are highly affected by soil erosion with an estimated average annual loss of 20 ton per hectare. Annually about 1 to 2 billion soil loss is reported for the country. The country-wise damage of soil erosion in economic term is indicated as losses of USD 1 billion annually. The situation threatened the food security of present and future generations as the smallholder farmers largely depend upon the soil for their livelihood. Out of a total surface area of 112 million hectares, about 27 million hectares are significantly eroded, 14 million hectares are seriously eroded with 2 million hectares have reached the point of no return.

The change in land use types played a significant role in this increased rate of soil erosion in Ethiopia. Cultivated lands showed continuously increasing trend at the expense of forest and grasslands. The rapidly increasing population has led to a declining availability of cultivable land and a very high rate of soil erosion.
Ethiopia historically passed significant dynamics in land use/land cover since long ago to date. Land use and land cover changes and degradation are increasing at alarming rate generally throughout the country and specifically in the highlands of Ethiopia that led to the transformation of natural habitats to other land use types. The original $65 \%$ of total forest coverage of the country was reduced to $2.2 \%$ in 2000 with current deforestation rate 80,000 to 200,000 ha per annum. This change in land use/land cover made agriculture of the country unsustainable, forcing its expansion into marginal areas such as steep slopes, swampy plains, and traditionally untapped part of the environment and putting tremendous pressure on soil, vegetation and water resources.

Land use/land cover changes and land degradation are highly interrelated because usually the changes are associated with deforestation, biodiversity loss and land degradation. The significant change in land use/land cover changes in highland parts of the country resulted in the soil degradation, mainly in the form of soil erosion, to be in worse sate. About half of the highlands' land area of Ethiopia was "significantly eroded" and over one-fourth was "seriously eroded" and over two million hectares of farm lands had reached the "point of no return". There are also different watershed and basin base reports that indicated the significant change in land use/land cover worsened the conditions of natural resource bases in general and soil specifically.

Therefore, Ethiopia passes significant change in land use/ land cover historically and this inappropriate use of land in Ethiopia for different uses made the condition of soil to be put in worst state. The situation will continue if no appropriate measure that brings sustainable natural resource use and management and that considers the need of both future and present generation is come in implementation. The current effort of the government in areas soil and water conservation should be increased more through the concept of integrated watershed management approach that bring different disciplines and areas of development in one board.

\section{References}

1. Hurni H, Zeleke G, Kassie M, Tegegne B, Kassawmar T, et al. ( 2015) Economics of Land Degradation (ELD): Ethiopia Case Study. Soil Degradation and Sustainable Land Management in the Rainfed Agricultural Areas of Ethiopia: An Assessment of the Economic Implications. Economics of Land Degradation 94. Link: https://tinyurl.com/y2vqcjd2

2. Azene BT (2001) Status and dynamics of natural resources in Ethiopia. In T. Assefa (ed.) Food Security through Sustainable Land Use: Population, Environment and Rural Development Issues for Sustainable Livelihoods in Ethiopia (165-184). Addis Ababa, Ethiopia: NOVIB Partners Forum on Sustainable Land Use.

3. Nyssen J, Moeyersons J, Deckers J, Haile M, Poesen J (2004) Vertic movements and the development of stone covers and gullies, Tigray highlands, Ethiopia. Zeitschrift für Geomorphologie 44: 145-164. Link: https://tinyurl.com/yxkvx3wj

4. Bojo J, Cassells D (1995) Land degradation and rehabilitation in Ethiopia: A reassessment. World Bank 1: 1-56. Link: https://tinyurl.com/y6p9f855

5. Yesuf M, Di Falco S, Deressa T, Ringler C, Kohlin G (2008) The impact of climate change and adaptation on food production in low-income countries. 
Evidence from the Nile Basin, Ethiopia. International Foodpolicy Research Institute. Link: https://tinyurl.com/yy264n5w

6. Hurni H (1989) Applied soil conservation research in Ethiopia. In: Thomas, DB (ed.) Soil and water conservation in Kenya. Nairobi, Kenya: University of Nairobi; Swedish International Development Authorit. 5-21. Link: https://tinyurl.com/yy59kfad

7. Sonneveld BG, Keyser MA (2003) Land under pressure: Soil conservation concerns and opportunities for Ethiopia. Land Degradation and Development 14: 5-23. Link: https://tinyurl.com/yxq8tosm

8. Teferi E, Bewket W, Simane B (2016) Effects of land use and land cover on selected soil quality indicators in the headwater area of the Blue Nile basin of Ethiopia. Environmental Monitoring and Assessment 188: 83. Link: https://tinyurl.com/yygzy9k8

9. Deresa F, Legesse T (2015) Cause of Land Degradation and Its Impacts on Livelihoods of the Population in Toke Kutaye Woreda, Ethiopia. International Journal of Scientific and Research Publications 5: 2250-3153. Link: https://tinyurl.com/y3m7fxtt

10. Hartemink AE (2003) Soil fertility decline in the tropics with case studies on plantations. International Soil Reference and Information Centre. Link: https://tinyurl.com/y44mxphy

11. Enters T (1998) Method for economic assessment of the on-and off-site impacts of soil erosion. Issues in Sustainable Land Management no. 2.

12. Lal R, Hall G, Miller F (1989) Soil degradation: I. Basic processes. Land Degrad Dev 1: 51-69. Link: https://tinyurl.com/yxegmnge

13. Temesgen G, Amare B, Abraham M (2014) Evaluations of Land Use/Land Cover Changes and Land Degradation in Dera District, Ethiopia: GIS and Remote Sensing Based Analysis. International Journal of Scientific Research in Environmental Sciences 2: 199-208. Link: https://tinyurl.com/y5vy9nw4

14. Amsalu A (2006) Caring for the land: Best practices in soil and water conservation in Beressa watershed, highlands of Ethiopia. Wageningen University 149. Link: https://tinyurl.com/y6tlwyqm

15. Awdenegest M, Holden NM (2007) Farmers' perceptions of soil erosion and soil fertility loss in southern Ethiopia. Land Degradation and Development 18 : 543-554. Link: https://tinyurl.com/y3yfmelt

16. Kassie M, Köhlin G, Bluffstone R, Holden S (2011) Are soil conservation technologies "win-win?" A case study of Anjeni in the north-western Ethiopian highlands. Nat Resour Forum 35: 89-99. Link: https://tinyurl.com/y4qazzaj

17. Ritter JP (2012) Soil Erosion: Causes and Effects. Ministry of Agriculture Food and Rural Affaires, Fact Sheet order No. 87-040, Ontario, Canada. Link: https://tinyurl.com/y7nqgbee

18. Balasubramanian A (2017) Soil Erosion: Causes and Effects. Technica Report, Research Gate, Ontario, Canada. Link: https://tinyurl.com/y6qjmatp

19. Hurni H (1993) Land degradation, famine, and land resource scenarios in Ethiopia. In: Pimentel, D. (Ed.) World Soil Erosion and Conservation, Cambridge. Cambridge University Press. Green Growth 27-62. Link: https://tinyurl.com/y5jheypo

20. Hurni H, Kebede T (1992) Erosion, Conservation, and Small-Scale Farming Geographical Bernensia: Bern, Switzerland.

21. Kebede W (2014) Effect of Soil and Water Conservation Measures and Challenges for its Adoption: Ethiopia in Focus. J Environmental Science and Technology 7: 185-199. Link: https://tinyurl.com/yyv6s7bl

22. Semu AA (2018) The impact of soil and water conservation for improved agricultural production in Ethiopia. Journal of Agriculture 1: 9-12. Link: https://tinyurl.com/y5cc9yw2

23. Teshome A, de Graaff J, Menale K (2016) Household-Level Determinants of
Soil and Water Conservation Adoption Phases: Evidence from North-Western Ethiopian Highlands. Journal of Environmental Management: 57: 620-636. Link: https://tinyurl.com/yyztcfge

24. Gete Z (2000) Landscape dynamics and soil erosion processes modelling in the north-western Ethiopia highlands. Africa studies series A16, University of Berne, Institute of Geography. Link: https://tinyurl.com/yyogfzn8

25. Kebrom T, Hedlund L (2000) Land cover changes between 1958 and 1986 in Kalu District, southern Wello, Ethiopia. Mountain Research and Development 20: 42-51. Link: https://tinyurl.com/y5q54dd7

26. Turner II BL, Meyer BL (1994) Global land use and land cover change: An overview. In Meyer WB, Turner BL II (Eds) Changes in land use and land cover: A global perspective. Cambridge University Press 23: 91-95. Link: https://tinyurl.com/y2admkas

27. Williams M (1994) Forest and tree cover. A global perspective. Cambridge university press $97-124$

28. Essays UK (2013) Land Use and Land Cover in Ethiopia Environmental Sciences Essay. Link: https://tinyurl.com/yy6emval

29. Forestry and Wildlife Conservation and Development Authority (FaWCDA) (1982) Forestry for Development; FaWCDA: Addis Ababa, Ethiopia 108

30. Pagiola S (1999) The global environmental benefits of land degradation control on agricultural land- global overlays program (English). The World Bank. Link: https://tinyurl.com/yxzgak72

31. Stocking MA (2001) Learn more about Land Degradation. In International Encyclopedia of the Social \& Behavioral Sciences. Link: https://tinyurl.com/y6kx4pyh

32. Safriel U, Adeel Z (2005) Dryland systems. In: Hassan R, Scholes R, Ash N (eds) Ecosystems and human wellbeing, current state and trends. Island Press 1: 625-658. Link: https://tinyurl.com/y6gpeagz

33. Karlen D, Rice CW (2015) Soil Degradation: Will Humankind Ever Learn? Journal of sustainability 7: 12490-12501. Link: https://tinyurl.com/y2wuacc7

34. Woldeamlak B, Sterk G (2002) Farmers' participation in soil and wate conservation activities in Chemoga Watershed, Blue Nile Basin, Ethiopia Land Degr Dev 13: 189-200. Link: https://tinyurl.com/y25wbkob

35. Bewke TW, Sterk G (2002) Farmers' participation in soil and water conservation activities in the Chemoga watershed, Blue Nile basin, Ethiopia. Land Degradation Development 13: 89-200. Link: https://tinyurl.com/ y4ty5dh4

36. Zenebe A, Bezaye G, Demeke N, Mowo J, Kidist H (2013) Farmers' Preference for Soil and Water Conservation Practices in Central Highlands of Ethiopia. African Crop Science Journal 21: 781-790. Link: https://tinyurl.com/yxf6wcbt

37. Zerihun N, Atsushi T, Nigussie H, Enyew A, Makoto N, et al. (2016) Farmers' Perception about Soil Erosion In Ethiopia. Land degradation and development 28: 401-411. Link: https://tinyurl.com/y4a88y46

38. Constable M, Belshaw D (1992) The Ethiopian highlands reclamation study: Major findings and recommendations. In Towards a Food and Nutrition Strategy for Ethiopia: Proceedings of the National Workshop on Food Strategies for Ethiopia; Office of the National Committee for Central Planning: Addis Ababa, Ethiopia. 8-12.

39. Mushir A, Kedru S (2012) Soil and water conservation management through indigenous and traditional practices in Ethiopia: a case study. Ethiopian Journal of Environmental Studies and Management 5: 343-355. Link: https://tinyurl.com/y65e6llw

40. Tegegne M, Biniam S (2017) Estimating Soil Erosion Risk and Evaluating Erosion Control Measures for Soil Conservation Planning at Koga Watershed, Highlands of Ethiopia. Journal of Solid Earth 8: 13-25. Link: https://tinyurl.com/yx8uj8tb 
41. Hurni H (1990) Degradation and conservation of soil resources in the Ethiopian highlands. Mountain Research and Development 8: 123-130. Link: https://tinyurl.com/yxmjgyql

42. Paulos D (2001) Soil and water resources and degradation factors affecting their productivity in the Ethiopian highland agroecosystems. Michigan State University Press. 8: 1-18. Link: https://tinyurl.com/y3yntey2

43. UNEP (2013) Adaptation to Climate-change Induced Water Stress in the Nile Basin: A Vulnerability Assessment Report. Nairobi, Kenya: Division of Early Warning and Assessment (DEWA), United Nations Environment Programme (UNEP). Link: https://tinyurl.com/y2memkaf

44. Stoorvogel JJ, Smaling EMA (1990) Assessment of soil nutrient depletion in sub-Saharan Africa 1983-2000. Vol. II: Nutrient balances per crop and per land use systems. International Soil Reference and Information Centre. Link: https://tinyurl.com/y4mhgmxo

45. Haregeweyn N, Tsunekawa A, Poesen J, Tsubo M, Meshesha DT, et al. (2017) Comprehensive assessment of soil erosion risk for better land use planning in river basins: Case study of the Upper Blue Nile River. Sci Total Environ 574 95-108. Link: https://tinyurl.com/y23xtfny

46. Amsalu A, de Graaff J (2007) Farmers' views of soil erosion problems and their conservation knowledge at Beressa watershed, central highlands of Ethiopia. Journal of Agriculture and Human 23: 99-108. Link: https://tinyurl.com/y6hvj6ce

47. Pimentel D, Harvey C, Resosudarmo P, Sinclair K, Kurz D, et al. (1995) Environmental and economic costs of soil erosion and conservation benefits. Science 267: 1117-1119. Link: https://tinyurl.com/y5jmg7jh

48. Bobe B (2004) Evaluation of soil erosion in the Hareghie region of Ethiopia using soil loss models, rainfall simulation and field trials. Pretoria University Link: https://tinyurl.com/y5zc4dot

49. Cerda A, Doerr SH (2005) Influence of vegetation recovery on soil hydrology and erodibility following fire: an 11-year investigation. Int J Wild land Fire 14 423-437. Link: https://tinyurl.com/y46t49un

50. Fan JR, Zhang JH, Zhong XH, Liu SZ, Tao HP (2004) Monitoring of soilerosion and assessmentfor contribution of sediments to rivers in a typical watershed of the Upper Yangtze River Basin. Land Degrad. Dev 15: 411-421. Link: https://tinyurl.com/y32xzct9

51. Ligonja PJ, Shrestha RP (2015) Soil erosion assessment in Kondoaeroded area in Tanzania using Universal Soil Loss Equation, geographic information systems and socioeconomic approach. Land Degrad Dev 26: 367-379. Link: https://tinyurl.com/y54ddxqc

52. Bezuayehu T, Gezahegn A, Yigezu A, Jabbar MA, Paulos D (2003) Nature and causes of land degradation in the Oromiya Region: A review. Socio-economics and Policy Research Working Paper 36. ILRI (International Livestock Research Institute), Nairobi, Kenya. 82. Link: https://tinyurl.com/y29ypjop

53. Berry L, Olson J, Campbell D (2003) Assessing the Extent Cost and Impact of Land Degradation at the National Level: Overview. Findings and Lessons Learned. Research Gate, Technical report. Link: https://tinyurl.com/y5vh7rtl

54. Woldeamlak B, Solomon A (2013) Land-use and land-cover change and its environmental implications in a tropical highland watershed, Ethiopia. International Journal of Environmental Study 70: 126-139. Link: https://tinyurl.com/yxvllfpo

55. Yohannes H, Mohammed A, Elias E (2017) Land Use/Land Cover Dynamics and Its Impact on Biodiversity Resources in the Abijata Shalla National Park Central Rift Valley Lakes Region, Ethiopia. Environ Sci Ind J 13: 152. Link: https://tinyurl.com/y23cql45

56. Gelet M, Suryabhagavan KV, Balakrishnan M (2010) Land-use and landscape pattern changes in holeta-berga watershed, Ethiopia. Int J Ecol Environ Sci 36: 117-132. Link: https://tinyurl.com/y3mny9lq
57. Aramde F, Demelash A, Yosef M (2014) Effects of Landuse and Land Cover Changes on the Extent and Distribution of Afroalpine Vegetation of Northern Western Ethiopia: The Case of Choke Mountains. Research Journal of Environmental Sciences 8: 17-28. Link: https://tinyurl.com/yy8xgkyr

58. Wubie MA, Assen M, Nicolau MD (2016) Patterns, causes and consequences of land use/cover dynamics in the Gumara watershed of Lake Tana basin, Northwestern Ethiopia. Journal of Environmental Systems Research 5. Link: https://tinyurl.com/yydpdcsd

59. Nigussie H, Samuel T, Atsushi T, Mitsuru T, Derege T, et al. (2015) Dynamics of land use and land cover and its effects on hydrologic responses: case study of the Gilgel Tekeze catchment in the highlands of Northern Ethiopia. $J$ Environ Monit Assess 187: Link: https://tinyurl.com/yy8asnel

60. Amare S, Gebeyehu A (2017) Land use and land cover change and implication to watershed degradation by using GIS and remote sensing in the Koga watershed, North Western Ethiopia. J Earth Sci Inform. Link: https://tinyurl.com/y4u8yxm8

61. Hagos G (2014) Land Use-Land Cover dynamics of Huluka watershed, Central Rift Valley, Ethiopia. International Soil and Water Conservation Research 2 25-33. Link: https://tinyurl.com/yxvq33km

62. Gebre SB, Merkel B, Agumassie T (2015) Land use and land cove dynamics in the dry Lake Haramaya Watershed in eastern Ethiopia using remote sensing. Journal of Freiberg Online Geoscience 43: 33-49. Link: https://tinyurl.com/y57hth8m

63. Belay HG (2018) Impact of Land Use/Land Cover Change on Rura Communities Livelihood of Ethiopia. Journal of Ecology and Environmental Science 6: 8-15. Link: https://tinyurl.com/y5twler9

64. EFD (2017) Understanding the dynamics and drivers of land use and land cover (LULC) change in Ethiopia. Environment for Development Initiative. Link: https://tinyurl.com/y6srhfok

65. Kassa T, Anton VR, Jean P, Simon VB, Jozef D, et al. (2014) Spatial analysis of land cover changes in eastern Tigray (Ethiopia) from 1965 to 2007: Are there signs of a forest transition? Land Degrad Dev 26: 680-689. Link: https://tinyurl.com/yyeoh7ph

66. Chakilu GG, Moges MA (2017) Assessing the Land Use/Cover Dynamics and its Impact on the Low Flow of Gumara Watershed, Upper Blue Nile Basin, Ethiopia. J Hydrology: Current Research 8: 268. Link: https://tinyurl.com/yy9qqc5q

67. Gete Z, Hurni H (2001) Implications of Land Use and Land Cover Dynamics for Mountain Resource Degradation in the Northwestern Ethiopian Highlands. Journal of Mountain Research and Development 21: 184-191. Link https://tinyurl.com/y64c8v93

68. Messay M (2011) Land-use/land-cover dynamics in Nonno district, Central Ethiopia. Journal of Sustainable Development in Africa 13: 123-139. Link: https://tinyurl.com/y6autpen

69. Mekuriya AD (2005) Forest coversion - soil degradation - farmers perception nexus: Implications for sustainable land use in the southwest of Ethiopia, Velk PLG, Denich M, Martius C, Rodgers C, van de Giesen N (eds). Center for development research, Ecology and Development Series No. 26, University of Bonn. Link: https://tinyurl.com/yygkhbnh

70. Lesschen JP, Verburg PH, Staal SJ (2005) Statistical methods for analyzing the spatial dimension of changes in land use and farming systems. LUCC Report Series No. 7. The International Livestock Research Institute, Nairobi, Kenya and Wageningen University, the Netherlands. Link: https://tinyurl.com/y5u4llow

71. Belay T (2002) Land-cover/land-use changes in the Derekolli catchment of the South Welo Zone of Amhara Region, Ethiopia. Michigan State University Press 18: 1-20. Link: https://tinyurl.com/yyrx3qsk 
72. Huffnagel (1961) Agriculture in Ethiopia. FAO, Rome.

73. Bout B (2016) The influence of land use change on soil erosion in the Genale catchment, Southern Ethiopia. Utrecht University Repository. Link: https://tinyurl.com/y23jhvej

74. Abera B (2003) Factors Influencing the Adoption of Soil Conservation Practices in Northwestern Ethiopia. Institute of Rural Development 37: 229235. Link: https://tinyurl.com/y3swl7qk

75. Adugna A, Abegaz A, Cerdà A (2015) Soil erosion assessment and control in Northeast Wollega, Ethiopia. Journal of Solid Earth 7: 3511-3540. Link: https://tinyurl.com/y6g3dt6x

76. Betrie GD, Mohamed YA, Van Griensven A, Srinivasan R (2011) Sediment management modelling in the Blue Nile Basin using SWAT model. Hydrology Earth System Science 15: 807-818. Link: https://tinyurl.com/y37vss8w

77. Bosshart U (1997) Catchment Discharge and Suspended Sediment Transport as Indicators of Physical Soil and Water Conservation in the Minchet Catchment, Anjeni Research Unit. Soil Conservation Research Report 40. Berne, Switzerland: University of Berne.

78. Coffey R (2013) The difference between "land use" and "land cover". Michigan State University Extension. Link: https://tinyurl.com/y27v7ddx

79. Combe A, Fisher P, Wadsworth R (2014) What is land cover? Environment and Planning B Planning and Design 32: 199-209. Link: https://tinyurl.com/y5jjwws2

80. Deresa F, Legesse T (2015) Cause of Land Degradation and Its Impacts on Livelihoods of the Population in Toke Kutaye Woreda, Ethiopia. International Journal of Scientific and Research Publications 5: 2250-3153. Link: https://tinyurl.com/y3m7fxtt

81. FAO (1986) Ethiopian highlands reclamation study. Final report. FAO, Italy Link: https://tinyurl.com/y52n9sfn
82. Geremew AA (2013) Assessing the impacts of land use and land cover change on hydrology of watershed: a case study on Gigel-Abbay Watershed. Lake Tana Basin, Ethiopia. Link: https://tinyurl.com/y2y3vbn2

83. Girma T (2001) Land Degradation: A Challenge to Ethiopia. Environ Manage 27: 815-824. Link: https://tinyurl.com/y2vx6pre

84. Haileslassie A, Priess J, Veldkamp E, Teketay D, Lesschen JP (2005) Assessment of soil nutrient depletion and its spatial variability on smallholders' mixed farming systems in Ethiopia using partial versus full nutrient balances. Agriculture, Ecosystems \& Environment 108: 1-16. Link: https://tinyurl.com/y6dp5tk7

85. Herweg K, Stillhardt B (1999) The Variability of Soil Erosion in the Highlands of Ethiopia and Eritrea. Average and Extreme Erosion Patterns. Soil Conservation Research Report 33. Berne, Switzerland: University of Berne.

86. Holmberg J (2000) Reconciling Conservation with Sustainable Development a Participatory Study inside and around the Simen Mountains National Park, Ethiopia. Mountain Research and Development 20: 382-384. Link: https://tinyurl.com/y5vum4b2

87. Mammo S, Kebin Z, Kidane M (2018) Retrospective analysis of land use land cover daynamics using GIS and remote sensing in central high lands of Ethiopia. Journal of Landscape Ecology 11: 31-52. Link: https://tinyurl.com/yxos6ppt

88. Muluneh A, Arnalds Ó (2011) Synthesis of Research on Land Use and Land Cover Dynamics in the Ethiopian Highlands. unpublished. Link: https://tinyurl.com/y2497nvt

89. Sisay NH, Teshome S, Demel T (2016) Land Use and Land Cover Change in the Bale Mountain Eco-Region of Ethiopia during 1985 to 2015. Journal of land 5 : 41. Link: https://tinyurl.com/y2madljz

90. Tamene L, Vlek PLG (2008) Soil Erosion Studies in Northern Ethiopia. Land Use and Soil Resources. 73-100. Link: https://tinyurl.com/y48alvyu

\section{Discover a bigger Impact and Visibility of your article publication with} Peertechz Publications

\author{
Highlights \\ * Signatory publisher of ORCID \\ * Signatory Publisher of DORA (San Francisco Declaration on Research Assessment) \\ * Articles archived in worlds' renowned service providers such as Portico, CNKI, AGRIS, \\ TDNet, Base (Bielefeld University Library), CrossRef, Scilit, J-Gate etc. \\ * Journals indexed in ICMJE, SHERPA/ROMEO, Google Scholar etc. \\ OAI-PMH (Open Archives Initiative Protocol for Metadata Harvesting) \\ * Dedicated Editorial Board for every journal \\ Accurate and rapid peer-review process \\ * Increased citations of published articles through promotions \\ * Reduced timeline for article publication \\ Submit your articles and experience a new surge in publication services \\ (https://www.peertechz.com/submission).
}

Peertechz journals wishes everlasting success in your every endeavours.

Copyright: (C) 2019 Tsegaye B. This is an open-access article distributed under the terms of the Creative Commons Attribution License, which permits unrestricted use, distribution, and reproduction in any medium, provided the original author and source are credited. 